\title{
Pemetaan Informasi Sebaran Bidang Ilmu Pada Skripsi Fakultas Teknologi Pertanian Lulusan IPB University Tahun 2015-2019 Berdasarkan Standar Universal Decimal Classification: Suatu Kajian Bibliometrika
}

\author{
Abdul Rahman Saleh ${ }^{1}$ dan Sri Rahayu ${ }^{2}$ \\ Perpustakaan IPB University \\ 12abdulr.saleh.2003@gmail.com, 2yayu.ikhwan@gmail.com
}

\begin{abstract}
Abstrak
Pendahuluan. Pertanian merupakan sektor penting bagi Indonesia. Salah satu sub sektor pertanian adalah industri dan mekanisasi pertanian. Kemajuan di bidang tersebut tidak terlepas dari kegiatan penelitian yang dilakukan oleh dosen, peneliti dan mahasiswa. IPB sebagai salah satu perguruan tinggi pertanian terkemuka tentu telah banyak menghasilkan penelitian di bidangnya. Untuk mengetahui dan memotret penelitian yang dilakukan oleh mahasiswa program sarjana maka penelitian ini dilakukan.
\end{abstract}

Metode dan Pengumpulan Data. Sampel dibatasi hanya pada skripsi 5 tahun terakhir (2015-2019) yang diambil dari repositori IPB.

Analisis Data. Pemetaan dilakukan berdasar pada Klasifikasi UDC. Tabel skripsi dianalisis secara deksriptif dan dipetakan menggunakan VosViewer.

Hasil dan Pembahasan. Jumlah penelitian skripsi Fakultas Teknologi Pertanian IPB selama 2015-2019 adalah 2.055 judul. Topik paling banyak diteliti adalah "produksi dan pengawetan makanan padat" berjumlah 461 penelitian dan paling sedikit adalah "ventilasi dan penyejukan udara" dan "industri karet" masing-masing hanya 2 penelitian. Kata kunci paling banyak adalah "teknik pengawetan makanan" dengan jumlah kemunculan sebanyak 278 kali. Kata kunci yang memiliki keterhubungan paling banyak adalah "teknik pengawetan makanan" dengan jumlah keterhubungan sebanyak 605 hubungan. Analisis kata kunci menggunakan VosViewer terbagi menjadi 16 kluster dengan kluster terbesar terdiri dari 69 kata kunci. Selanjutnya dosen pembimbing utama yang paling produktif membimbing mahasiswa adalah Arif Sabdo Yuwono (31 bimbingan), sedangkan sebagai pembimbing anggota paling produktif adalah Muhammad Arif Darmawan dan Didah Nur Faridah (masing-masing 19 bimbingan).

Kesimpulan. Topik paling diminati adalah "produksi dan pengawetan makanan padat" (461 judul). Kata kunci paling banyak adalah "teknik pengawetan makanan" dengan kemunculan sebanyak 278 kali. Dosen pembimbing utama paling produktif adalah Arif Sabdo Yuwono dengan jumlah bimbingan sebanyak 31 mahasiswa.

Kata kunci: Teknologi pertanian, teknologi industri pertanian, skripsi mahasiswa, tugas akhir program sarjana.

\begin{abstract}
Introduction. Agriculture is an important sector for Indonesia. One of the agricultural sub-sectors is industry and agricultural mechanization. Progress in this field cannot be separated from research activities carried out by lecturers, researchers and students. $I P B$ as one of the leading agricultural universities has certainly produced a lot of research in its field. To find out and photograph the research conducted by undergraduate students, this research was conducted.
\end{abstract}

Methods and Data Collection. The sample is limited to the thesis of the last 5 years (2015-2019) which is taken from the IPB repository.

Data analysis. Mapping is reviewed based on the UDC Classification. The table was analyzed descriptively and mapped using VosViewer.

Results and Discussion. The number of thesis researches of the Faculty of Agricultural Technology, IPB during 2015 2019 is 2,055 titles. The most researched topics were "production and preservation of solid food" totaling 461 studies and the least were "ventilation and air conditioning" and "rubber industry" with only 2 studies each. The most common keyword is "food preservation techniques" with 278 occurrences. The keyword that has the most correlation is "food preservation techniques" with a total of 605 relationships. Keyword analysis using VosV iewer is divided into 16 clusters with the langest cluster consisting of 
69 keywords. Furthermore, the main supervisor who was the most productive in guiding students was Arif Sabdo Yuwono (31 mentors), while the most productive supervisors were Muhammad Arif Darmawan and Didah Nur Faridah (19 each).

Conclusion. The topic of most interest is "production and preservation of solid foods" (461 titles). The most common keyword is "food preservation techniques" with 278 occurrences. The most productive main supervisor is Arif Sabdo Yuwono with a total of 31 students.

Keywords: Agricultural technology, agricultural industrial technology, student thesis, undergraduate final project.

\section{PENDAHULUAN}

Sebagaimana diketahui bahwa Indonesia sampai saat ini masih tergolong sebagai negara agraris. Hal ini disebabkan karena mayoritas penduduknya masih bekerja di sektor pertanian. Sektor pertanian tersebut merupakan penyumbang Produk Domestik Bruto (PDB) terbesar yaitu sebesar 20\% dan menyerap 50\% tenaga kerja di pedesaan (Gischa, 2019). Pernyataan Said dan Intan (2001) sebagaimana dikutip oleh (Nugroho, 2015) menguatkan pernyataan tersebut yaitu bahwa Indonesia masih merupakan negara agraris di mana menurutnya $70 \%$ penduduk Indonesia bekerja di sektor pertanian. Oleh karenanya sektor pertanian ini menjadi hal yang sangat perlu mendapat perhatian. Dalam hal sumbangan sektor pertanian terhadap PDB ini Sutanto berpendapat lain. Menurut Sutanto sumbangan terbesar PDB Indonesia adalah justru berasal dari sektor industri yaitu sebesar 19,66\% dibandingkan sektor pertanian yang hanya 15,53\% (Susanto, 2018). Data tersebut memang diperoleh dari tahun yang berbeda. Namun sektor industri tersebut juga sebagian besar merupakan industri yang berbasis pada pertanian seperti industri pengolahan hasil pertanian, peternakan dan perikanan.

Dalam upaya memperkuat sektor pertanian maka kita harus memahami sifat dari produk pertanian tersebut. Kita tahu bahwa sifat produk pertanian pada umumnya: (a) tidak awet atau mudah atau mudah busuk sehingga hasil pertanian harus segera dikonsumsi; (b) berumur pendek sehingga sulit disimpan untuk cadangan atau persediaan makanan; (c) sulit didistribusikan dalam bentuk aslinya karena bentuk dan ukurannya yang makan tempat (bulky). Untuk mengatasi kelemahan-kelemahan tersebut maka diperlukan penanganan hasil pertanian seperti perawatan, penyimpanan, dan pengemasan yang baik. Di dalam distribusi produk hasil pertanian harus dilakukan dengan cepat dan dengan pengepakan yang baik dan benar. Dengan kata lain maka penanganan terhadap hasil pertanian tersebut memerlukan teknologi.

Dalam hal produksi, maka pertanian memerlukan lahan yang tidak sedikit. Sebagaimana kita ketahui bahwa lahan merupakan salah satu faktor produksi selain tenaga kerja, modal dan manajemen (Agrotek Pertanian, 2017). Saat ini kebutuhan lahan untuk pertanian tersebut bersaing dengan sektor pemukiman. Maulana mengutip data Badan Pusat Statistik menyebutkan luas lahan sawah di Indonesia telah berkurang dari 7,74 juta hektar di tahun 2017 menjadi 7,1 juta hektar di tahun 2018 (Maulana, 2019). Banyak daerah yang tadinya menjadi lumbung beras, sekarang sudah berdiri pemukiman dan bahkan pabrik. Pertanian semakin tersisih. Agar produksi pertanian dapat tetap dipertahankan, maka diperlukan berbagai rekayasa seperti rekayasa cuaca, rekayasa kesuburan tanah, penggunaan mesin-mesin pertanian, serta teknologi pengairan. Dengan berbagai rekayasa dan teknologi diharapkan pertanian tetap dapat diandalkan dengan produktivitas yang tinggi walaupun banyak lahan yang beralih fungsi menjadi non pertanian.

Pentingnya teknologi tersebut tercermin dalam kebijakan industri nasional dalam pemerintahan presiden Joko Widodo. Dalam Perpres Nomor 2 Tahun 2018 disebutkan ada sebelas sasaran industri nasional. Dari kesebelas sasaran tersebut beberapa terkait dengan industri bidang pertanian, misalnya pada fokus sasaran industri disebutkan antara lain sebagai berikut: "Peningkatan nilai tambah sumber daya alam pada industri hulu berbasis agro, mineral, serta migas dan batu bara dalam rangka pendalaman struktur industri melalui penguatan rantai nilai industri dan pembangunan industri hulu yang diintegrasikan dengan industri antara dan industri 
hilimya." Selanjutnya dikatakan bahwa pengembangan dan pemanfaatan teknologi industri dilakukan melalui penguatan infrastruktur penelitian dan pengembangan, peningkatan adopsi dan alih teknologi, serta pemanfaatan teknologi industri dalam negeri (Kementerian Sekretariat Negara RI, 2015).

Penelitian dan pengembangan merupakan kegiatan yang wajib dilakukan untuk memajukan suatu bangsa. Penelitian adalah sebuah proses kegiatan mencari kebenaran terhadap suatu fenomena ataupun fakta yang terjadi dengan cara yang terstruktur dan sistematis. Sedangkan pengembangan adalah suatu usaha untuk meningkatkan kemampuan teknis, teoritis, konseptual, dan moral sesuai dengan kebutuhan melalui pendidikan dan latihan. Kegiatan penelitian dan pengembangan tersebut dilakukan salah satunya oleh perguruan tinggi.

IPB University sebagai salah satu perguruan tinggi bidang pertanian terkemuka memiliki tanggung jawab besar dalam mendukung program pemerintah dalam mengembangkan pertanian secara umum dan khususnya bidang industri dan teknologi berkaitan dengan pertanian. Tentunya di Institut Pertanian Bogor telah dilakukan penelitian terkait bidang tersebut baik oleh dosen/peneliti dan mahasiswa. Dosen melakukan penelitian dalam kaitannya dengan kewajiban sebagai tugas dosen dalam tri dharma perguruan tinggi, sedangkan mahasiswa melakukan penelitian sebagai bagian dari kewajibannya untuk menyelesaikan studinya di perguruan tinggi. Untuk mengetahui sejauh mana bidang atau topik penelitian yang sudah dilakukan di IPB University, khususnya yang dilakukan oleh mahasiswa program sarjana, di bidang teknologi industri hasil pertanian dan teknologi mekanisasi pertanian di IPB maka perlu dilakukan penelitian atau kajian pemetaan hasilhasil penelitian tersebut.

Ruang lingkup penelitian ini dibatasi hanya pada data tugas akhir atau skripsi mahasiswa program sarjana atau strata 1 (S1) di Fakultas Teknologi Pertanian IPB University. Tahun skripsi dibatasi hanya dari tahun kelulusan 2015 sampai dengan tahun kelulusan 2019, atau selama 5 tahun.
Penelitian ini bertujuan untuk:

1. Mengetahui sebaran topik penelitian bidang teknologi pertanian pada tugas akhir (skripsi) mahasiswa program sarjana Fakultas Teknologi Pertanian, IPB University.

2. Membuat peta bidang ilmu pada penelitian mahasiswa program sarjana Fakultas Teknologi Pertanian IPB berdasarkan kelompok bidang ilmu dalam standar Universal Decimal Classification.

3. Mengetahui produktivitas dosen Fakultas Teknologi Pertanian IPB dalam membimbing skripsi mahasiswa S1 selama 5 tahun terakhir (2015 - 2019).

4. Menampilkan peta jalan (roadmap) penelitian mahasiswa tingkat sarjana di Fakultas Teknologi Pertanian IPB University yang merupakan bagian dari peta jalan (roadmap) penelitian mahasiswa tingkat sarjana di Institut Pertanian Bogor selama 5 tahun terakhir.

\section{TINJAUAN PUSTAKA}

Salah satu modal utama manusia untuk meraih keberhasilan dalam kehidupannya adalah penguasaan terhadap ilmu pengetahuan dan teknologi. Oleh karena itu maka penguasaan terhadap ilmu pengetahuan dan teknologi tersebut menjadi sangat penting. Ilmu pengetahuan dan teknologi harus dimiliki oleh setiap manusia, karena dengan ilmu pengetahuan dan teknologi kita bisa menghadapi dan menyelesaikan permasalahan. Bahkan, karena pentingnya peran ilmu pengetahuan dan teknologi tersebut maka penguasaan ilmu pengetahuan dan teknologi sering dijadikan barometer atau ukuran maju mundurnya suatu bangsa.

Ilmu pengetahuan dan teknologi dapat ditransfer melalui komunikasi lisan seperti yang terjadi pada kuliah, seminar, dan sejenisnya. Ilmu pengetahuan yang seperti ini kita kenal dengan tacit knowledge. Namun transfer ilmu pengetahuan tersebut dapat pula dilakukan melalui sebuah penulisan. Ilmu pengetahuan yang demikian dikenal dengan explicit knowledge. Penulisan karya ilmiah termasuk dalam kategori transfer ilmu pengetahuan explicit knowledge. Penulisan karya ilmiah tersebut merupakan 
sebuah kegiatan yang wajib dilakukan di perguruan tinggi mana pun di dunia. Karya ilmiah harus ditulis sesuai dengan tata cara ilmiah yaitu dengan berpedoman kepada panduan penulisan karya ilmiah yang berstandar yang diberlakukan di perguruan tingginya. Melalui karya ilmiah tersebut masyarakat perguruan tinggi dapat berkomunikasi dan mengetahui perkembangan dalam bidang ilmu yang ditekuninya. Salah satu jenis karya ilmiah di perguruan tinggi adalah skripsi. Pengertian skripsi menurut Tanjung adalah (Tanjung \& Ardial, 2007):

"Skripsi dan tesis merupakan hasil
penelitian lapangan adalah jenis
penelitian yang berorientasi pada
pengumpulan data empiris di lapangan.
Ditinjau dari pendekatan yang
digunakan, penelitian lapangan dapat
dibedakan menjadi dua macam, yaitu
penelitian kuantitatif dan penelitian
kualitatif."

Di perpustakaan ilmu tersebut dikelompokkan ke dalam kelompok bidang ilmu untuk memudahkan penyimpanan dan temu balik informasi. Di lingkungan perpustakaan dikenal beberapa standar pengelompokan bidang ilmu seperti antara lain: (a) Dewey Decimal Classification, (b) Universal Decimal Classification, (c) Library of Congress Classification, (d) International Classification for Standard, dan lain-lain. Sebagian besar perpustakaan di Indonesia menggunakan standar klasifikasi Dewey Decimal Classification atau yang dikenal dengan DDC dan sebagian lagi, terutama perpustakaan bidang kekhususan, menggunakan Universal Decimal Classification atau UDC. Institut Pertanian Bogor merupakan jenis perpustakaan perguruan tinggi yang memiliki kekhususan di bidang pertanian. Oleh karena itu Perpustakaan IPB menggunakan Universal Decimal Classification.

Universal Decimal Classification atau UDC adalah salah satu skema klasifikasi yang digunakan oleh perpustakaan dalam mengelompokkan bahan perpustakaan berdasarkan subyeknya yang dinyatakan dengan nomor kelas. Sistem klasifikasi UDC dibagi menjadi sepuluh kelompok ilmu atau disebut kelas, dan masing-masing kelas tersebut dibagi lagi menjadi bagian-bagian logis, masing-masing sub divisi kemudian dibagi lagi dan seterusnya (Sulistyo-Basuki, 1991). Kelompok utama bidang ilmu pengetahuan diatur dalam 10 kelas dan diberi nomor 0 sampai 9 sebagai berikut: (0) Sain dan Pengetahuan. Organisasi, Ilmu Komputer, Ilmu Informasi, Dokumentasi, Kepustakawanan, Lembaga, dan Publikasi; (1) Filsafat dan Psikologi; (2) Agama atau Teologi; (3) Ilmu sosial, (4) Kosong (tidak digunakan); (5) Matematika, dan Ilmu Pengetahuan Alam; (6) Ilmu Terapan, Kedokteran dan Teknologi (7) Seni dan Olah Raga; (8) Linguistik dan Literatur; (9) Geografi dan Sejarah (Concortium, 2019).

Cabang ilmu Teknologi Pertanian di mana di dalamnya termasuk teknologi industri pertanian, mekanisasi pertanian serta bidang yang berkaitan seperti teknologi kimia, lingkungan, dan biosistem, tersebar di beberapa kelompok atau kelas. Di kelas 62 ada teknik sipil seperti pembangunan dam dan irigasi. Di kelas 63 ada industri pengolahan hasil ternak seperti pembuatan mentega, minyak dan lain-lain. Sedangkan di kelas 66 merupakan kelompok yang terbanyak seperti antara lain industri kimia, pengolahan bahan makanan dan produk pertanian, serta industri pengawetan bahan makanan. Sebagian berada dalam kelas 67 seperti industri pengolahan kayu (pulp), industri kulit, industri tekstil atau pengolahan serat, dan lain-lain. Sub kelompok yang cukup besar tersebut kemudian dibagi lagi menjadi bidang yang lebih spesifik. Dapat disimpulkan bahwa makin khusus atau makin spesifik suatu subyek, maka semakin panjang notasinya karena banyak angka yang ditambahkan pada notasi dasarnya.

Penelitian sejenis yang pernah dilakukan adalah pada tahun 2019 oleh Ratnaningsih dan Aat Atnah dengan judul "Pemetaan Bidang Ilmu Pada Skripsi Fakultas Ekologi Manusia Lulusan Tahun 2014-2018 Berdasarkan Standar Universal Decimal Classification" (Ratnaningsih \& Atnah, 2019). Penelitian ini menyimpulkan bahwa: (1) Jumlah penelitian skripsi mahasiswa Fakultas Ekologi Manusia IPB selama 2014-2018 berjumlah 1.814 penelitian; (2) Hasil penelitian mahasiswa Strata 1 Fakultas Ekologi Manusia yang tertinggi di Departemen Gizi Masyarakat yang banyak di teliti adalah Konsumsi Pangan (223 judul); Status Gizi (147 judul) dan 
Pengetahuan Gizi (150 judul). Untuk bidang lainnya, dapat dijadikan peluang untuk dijadikan bidang penelitian; (3) Dosen pembimbing yang paling produktif membimbing mahasiswa selama kurun waktu 2014-2018 adalah M Rizal Martua Damanik sebanyak 54 bimbingan mahasiswa. Penelitian kedua dilakukan oleh Saleh dan Himawan dengan judul "Pemetaan Informasi Sebaran Bidang Ilmu pada Penelitian Skripsi Fakultas Perikanan dan Ilmu Kelautan IPB Lulusan Tahun 2014-2018 Berdasarkan Standar Universal Decimal Classification' (Saleh \& Himawan, 2019). Penelitian ini menyimpulkan antara lain: (1) Bidang yang menjadi penelitian mahasiswa FPIK terdiri dari dua kelompok besar yaitu bidang yang terkait komoditas perikanan (sebanyak 546 judul atau 29,90\%) dan bidang non-komoditas perikanan (sebanyak 1280 judul atau 70,10\%); (2) Penelitian terkait komoditas perikanan terdiri dari mengenai komoditas ikan (sebanyak 347 penelitian atau $63,55 \%$ ) dan komoditas non-ikan (sebanyak 199 penelitian atau 36,45\%); (3) Ikan lele merupakan jenis ikan yang terbanyak menjadi obyek penelitian pada kelompok penelitian tentang ikan air tawar yaitu sebanyak 64 penelitian, sedangkan ikan baung, lelawak, uceng, dan tambakan merupakan jenis ikan yang paling sedikit diteliti yaitu masing-masing hanya 1 penelitian. Sedangkan pada jenis ikan laut/payau, ikan sidat merupakan ikan yang paling banyak diteliti (21 penelitian). Ikan baronang dan swanggi merupakan ikan yang paling sedikit diteliti; (3) Dosen paling produktif membimbing adalah Agoes Mardiono Jacoeb dengan jumlah bimbingan sebanyak 81 mahasiswa. Penelitian yang ketiga dilakukan oleh Ratnaningsih dkk dengan judul Peta Penelitian Terhadap 12 Jenis Buah Lokal Indonesia Pada Skripsi, Tesis dan Disertasi Lulusan IPB (Ratnantingsih, Himawan, \& Saleh, 2019). Penelitian ini menyimpulkan bahwa: (1) Penelitian terkait 12 jenis buah tropika baik pada skripsi, tesis, maupun disertasi belum begitu intensif. Bahkan pada disertasi ada lima jenis buah dari 12 jenis buah lokal selama 20122016 tidak ada yang meneliti; (2) Pada penelitian program sarjana (skripsi) buah yang paling banyak diteliti selama 2012-2016 adalah buah pisang sedangkan yang paling sedikit adalah buah semangka. Pada program pascasarjana (tesis) buah yang paling banyak diteliti selama 2012-2016 adalah buah jeruk dan paling sedikit adalah buah semangka. Sedangkan pada program doktor buah yang paling banyak diteliti selama 2012-2016 adalah buah manggis, sedangkan buah alpukat, rambutan, pepaya, melon, dan semangka sama sekali tidak ada yang meneliti; dan (3) Bidang yang paling banyak dikaji adalah bidang budidaya tanaman dan teknologi agroindustri. Sedangkan bidang-bidang lainnya masih sangat berpeluang untuk dijadikan bidang penelitian.

Penelitian keempat dilakukan oleh Deden Himawan dan Ratnaningsih dengan judul Penelitian Peningkatan Layanan Data dan Informasi dalam Rangka Memenuhi Kebutuhan Informasi di Perpustakaan Perguruan Tinggi: suatu kajian deskriptif analisis terhadap 5 bunga komersial utama dan 7 bunga potensial komersial (Ratnaningsih \& Himawan, 2016). Kajian ini menyimpulkan bahwa: (1) Penelitian belum dilakukan secara merata terhadap masing-masing jenis dari 5 jenis bunga komersial dan 7 bunga potensial komersial karena belum adanya penelitian terkait beberapa bunga jenis tertentu; (2) Anggrek merupakan jenis bunga yang paling banyak diteliti oleh mahasiswa program sarjana (skripsi), pascasarjana (tesis), maupun doktor (disertasi); (3) Bidang yang paling banyak dikaji adalah bidang budidaya pertanian. Untuk bidang lainnya, dapat dijadikan peluang untuk dijadikan bidang penelitian; (4) Peta/roadmap terkait 5 bunga komersial dan 7 bunga potensial komersial merupakan salah satu bentuk produk perpustakaan dalam layanan data dan informasi kepada pengguna khususnya kelompok pimpinan; (5) Peta/roadmap terkait 5 bunga komersial dan 7 bunga potensial komersial dapat menjadi masukan kepada kelompok pimpinan dalam pengambilan keputusan maupun kebijakan dalam mendukung pengembangan bunga nusantara.

Penelitian kelima dilakukan oleh Saleh pada tahun 2018 dengan judul "Pemetaan Bidang Ilmu pada Skripsi Fakultas Peternakan IPB lulusan 2012 - 2016 sesuai Universal Decimal Classification" (Saleh, 2018) Penelitian ini menyimpulkan: (1) Diketahui bahwa bidang ilmu yang menjadi topik penelitian mahasiswa terbanyak untuk penulisan skripsinya adalah 
bidang ilmu pakan ternak yang terdiri dari pakan dan teknologi pakan ternak sebanyak 328 judul penelitian atau 31,1\% dari seluruh skripsi dan hijauan pakan ternak sebanyak 181 judul penelitian atau $17,2 \%$ dari total skripsi; (2) Skripsi di luar bidang pakan ternak berjumlah 546 judul penelitian atau sebesar $51,8 \%$ yang terdiri dari (diurut berdasarkan jumlah penelitian yang paling besar) pemuliaan dan genetika ternak, ternak unggas, daging, sosial ekonomi peternakan, sistem peternakan (farm), ternak lain-lain, susu, ruminan kecil, bakteriologi, reproduksi, ruminansia besar, hasil ternak selain makanan, telur, keluarga lebah/ serangga, fisiologi, ternak kerja/ rekreasi, burung non unggas, kelinci, dan ternak babi; (3) Tiga orang dosen paling produktif sebagai ketua pembimbing skripsi adalah Dr. Irma Isnafia Arief, S.Pt, M.Si. (39 bimbingan), diikuti Muhamad Baihaqi, S.Pt, M.Sc. (36 bimbingan), dan Prof. Dr. Ir. Cece Sumantri dan Dr. Ir. Rita Mutia, M.Agr. (masing-masing dengan 30 bimbingan).

\section{METODE PENELITIAN}

Penelitian ini merupakan penelitian kombinasi antara kualitatif dan kuantitatif (mixed methods). Digunakan metode kombinasi karena peneliti ingin memperoleh data dan informasi yang lengkap, valid, reliable, dan obyektif. Penelitian kualitatif sendiri merupakan penelitian tentang riset yang bersifat deskriptif dan cenderung menggunakan analisis. Proses dan makna lebih ditonjolkan dalam penelitian kualitatif. Sedangkan penelitian kuantitatif merupakan penelitian ilmiah yang sistematis terhadap bagian-bagian dan fenomena serta hubungan-hubungannya. Tujuan penelitian kuantitatif adalah mengembangkan dan menggunakan model matematis, teori dan/atau hipotesis yang berkaitan dengan fenomena alam (Sugiyono, 2014). Terhadap hasil pengamatan dan wawancara dilakukan analisis deskriptif di mana analisis deskriptif diartikan sebagai analisis yang dilakukan untuk menilai karakteristik dari sebuah data (Hidayat, 2012). Analisis deskriptif menurut Sugiyono adalah suatu metode yang berfungsi untuk mendeskripsikan atau memberi gambaran terhadap obyek yang diteliti melalui data atau sampel yang telah terkumpul sebagaimana adanya tanpa melakukan analisis dan membuat kesimpulan yang berlaku untuk umum
(Sugiyono, 2014). Data dan teknik sampel populasi dari obyek penelitian ini adalah seluruh skripsi lulusan Fakultas Teknologi Pertanian dari lulusan tahun 1968 sampai lulusan tahun 2019. Sedangkan sampel ditarik berdasarkan purposive sampling dengan batasan tahun 2015 sampai tahun 2019. Data skripsi diambil dari basis data skripsi di Perpustakaan IPB dengan batasan 2015-2019. Data kemudian ditabulasi berdasarkan kelompok bidang ilmu standar Universal Decimal Classification. Tabel yang dihasilkan kemudian dianalisis secara deskriptif.

Untuk melengkapi analisis kuantitatif dilakukan wawancara dengan para nara sumber atau informan yang memiliki kewenangan pengambil kebijakan dalam bidang penelitian tugas akhir seperti Ketua Departemen, Kepala Laboratorium, dan Pimpinan Fakultas (Dekan, serta Wakil Dekan). Wawancara dilakukan secara tidak terstruktur dengan mengacu kepada panduan wawancara. Teknik sampel menggunakan non-probability sampling yaitu tidak memberikan peluang/ kesempatan yang sama bagi setiap unsur populasi untuk dipilih menjadi sampel (Sugiyono, 2014).

Data dari sampel basis data skripsi dan informasi dari hasil wawancara akan diolah dengan cara ditabulasi, kemudian tabulasi dianalisis secara deskriptif kualitatif. Analisis data adalah proses mencari dan menyusun secara sistematis data yang diperoleh dari data dan hasil observasi, wawancara, catatan lapangan, dan dokumentasi, dengan cara mengorganisasikan data ke dalam kategori, menjabarkan ke dalam unit-unit, melakukan sintesis, menyusun ke dalam pola, memilih mana yang penting dan yang akan dipelajari, dan membuat kesimpulan sehingga mudah dipahami oleh diri sendiri maupun orang lain (Sugiyono, 2014). Khusus untuk data kualitatif dilakukan menggunakan metode analisis maju bertahap menurut Spradley (1980) sebagaimana dikutip oleh Muljono dkk di mana analisis data dilakukan bersamaan dengan pengumpulan data, artinya ketika dilakukan observasi saat itu pula dilakukan wawancara tahap tersebut. Hasil observasi dan wawancara tersebut kemudian dianalisis dan hasilnya digunakan untuk melakukan observasi dan wawancara tahap berikutnya (Muljono, Sujana, \& Prabowo, 2009). 
Aplikasi VosViewer yang dikembangkan oleh Nees Jan van Eck and Ludo Waltman digunakan untuk menyajikan peta kata kunci atau co-word dan kepadatan kata kunci (density visualization) yang muncul dalam dokumen skripsi Fakultas Teknologi Pertanian IPB tahun 20152019. Aplikasi VosViewer merupakan program aplikasi komputer yang dapat digunakan untuk melihat peta bibliometrik (Tupan, 2016). Sedangkan menurut Purwoko aplikasi VosViewer salah satunya digunakan untuk memvisualkan bibliografi, atau data set yang berisi field bibliografi dan dalam penelitian, aplikasi ini digunakan untuk analisis bibliometrik serta mencari topik yang masih memiliki peluang untuk diteliti (Purwoko, 2020). Untuk mendapatkan peta co-word atau kata kunci pada penelitian mahasiswa, kajian ini menelusuri kata kunci yang digunakan oleh mahasiswa pada saat melakukan unggah mandiri skripsinya ke basis data Perpustakaan IPB. Kata kunci yang dibuat oleh mahasiswa tersebut kemudian diseleksi dan divalidasi untuk mendapatkan kata kunci yang memiliki makna lengkap yaitu membuang kata kunci yang salah dan kata kunci yang tidak memiliki arti secara utuh. Kemudian kata kunci tersebut diterjemahkan ke dalam bahasa Indonesia sebelum dioleh menggunakan VosViewer.

\section{HASIL DAN PEMBAHASAN}

\section{Gambaran umum penelitian mahasiswa Fateta IPB}

Kajian ini mempelajari skripsi Fakultas Teknologi Pertanian sebanyak 2.055 judul selama kurun waktu lima tahun yaitu dari tahun 2015 sampai dengan 2019. Skripsi tersebut merupakan skripsi dari empat departemen yang berada di Fakultas Teknologi Pertanian yaitu: Departemen Teknik Mesin dan Biosistem (TMB), Departemen Ilmu dan Teknologi Pangan (ITP), Departemen Teknologi Industri Pertanian (TIN), Departemen Teknik Sipil dan Lingkungan (SIL). Sebaran jumlah skripsi mahasiswa menurut departemen tersebut terlihat seperti pada tabel 1 berikut.

Tabel 1 Sebaran skripsi menurut departemen pada Fakultas Teknologi Pertanian IPB lulusan tahun 2015-2019

\begin{tabular}{rlrrrrrr}
\hline \multirow{2}{*}{ No. } & Dept & \multicolumn{5}{c}{ Tahun } & \multirow{2}{*}{ Jumlah } \\
\cline { 3 - 6 } & & $\mathbf{2 0 1 5}$ & $\mathbf{2 0 1 6}$ & $\mathbf{2 0 1 7}$ & $\mathbf{2 0 1 8}$ & $\mathbf{2 0 1 9}$ & \\
\hline 1 & TMB & 103 & 95 & 100 & 116 & 105 & 519 \\
2 & ITP & 102 & 128 & 154 & 101 & 122 & 607 \\
3 & TIN & 118 & 109 & 125 & 123 & 97 & 572 \\
4 & SIL & 65 & 81 & 80 & 62 & 69 & 357 \\
\hline & Jumlah & 388 & 413 & 459 & 402 & 393 & 2055 \\
\hline
\end{tabular}

Dari tabel tersebut terlihat bahwa dari total penelitian skripsi mahasiswa Fakultas Teknologi Pertanian selama kurun waktu 2015-2019 yaitu sebanyak 2.055 di mana penelitian terbanyak adalah pada tahun 2017 yaitu sebanyak 459 penelitian (22,34\%). Sedangkan jumlah penelitian kedua terbanyak adalah pada tahun 2016 yaitu sebanyak 413 penelitian (20,10\%), kemudian tahun 2018 sebanyak 402 penelitian (19,56\%), tahun 2019 sebanyak 393 penelitian (19,12\%) dan yang paling sedikit adalah pada tahun 2015 yaitu sebanyak 388 penelitian $(18,88 \%)$, penelitian skripsi terbanyak adalah penelitian yang dilakukan oleh departemen ITP yaitu sebanyak 607 penelitian (29,54\%), diikuti oleh departemen TIN sebanyak 572 penelitian $(27,83 \%)$, kemudian oleh departemen TMB sebanyak 519 penelitian
$(25,26 \%)$ dan yang terakhir oleh departemen SIL sebanyak 357 penelitian 17,37\%).

\section{Sebaran Bidang Ilmu}

Penelitian-penelitian yang dilakukan oleh mahasiswa dalam rangka penyusunan skripsinya tersebut berada di empat wilayah kelompok keilmuan utama menurut UDC yaitu kelompok umum atau dalam UDC Daring disebut sebagai kelompok Sain dan pengetahuan (kelas 000), kelompok ilmu pengetahuan sosial (kelas 300), kelompok ilmu-ilmu murni dan ilmu pengetahuan alam (kelas 500) dan kelompok ilmu terapan (kelas 600).

Grafik pada gambar 2 memperlihatkan komposisi penelitian dari ketiga kelompok keilmuan tersebut. 


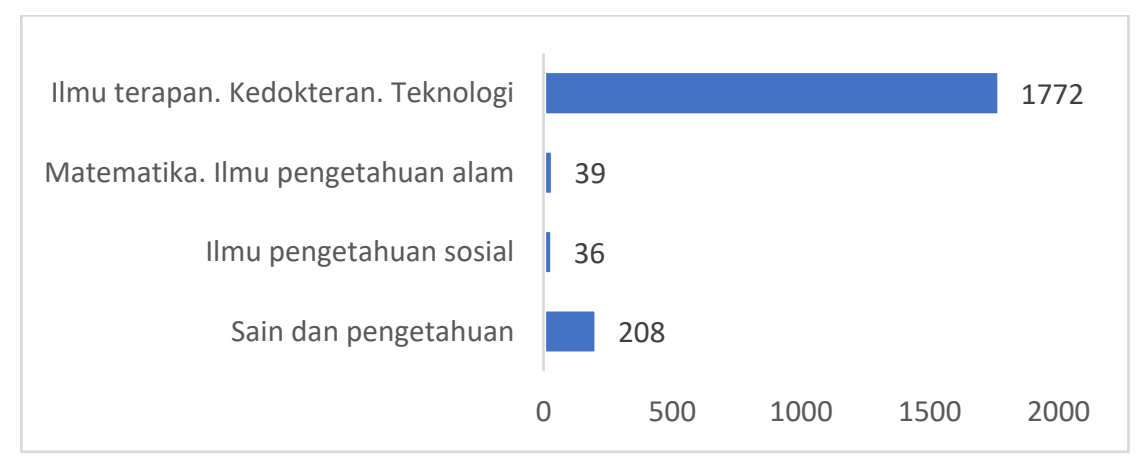

Gambar 1 Sebaran penelitian mahasiswa Fakultas Teknologi Pertanian IPB menurut kelompok bidang ilmu utama atau level satu menurut UDC selama kurun waktu 2015-2019

Dari gambar 1 terlihat bahwa sebagian besar mahasiswa meneliti bidang yang terkait ilmu-ilmu terapan. Hal ini sangat wajar sebab bidang ilmu di lingkungan Fakultas Teknologi Pertanian memang berada dalam kawasan ilmuilmu terapan. Dalam UDC, bidang teknologi pertanian sebagian besar berada pada kelompok atau kelas 6 yaitu ilmu-ilmu terapan. Jumlah penelitian pada bidang ilmu terapan tersebut sebanyak 1772 penelitian (86,23\%). Sisanya tersebar di tiga bidang ilmu utama UDC yaitu sebanyak 208 penelitian $(10,12 \%)$ pada bidang ilmu Sain dan Pengetahuan (kelas 0), sebanyak 39 penelitian $(1,90 \%)$ pada bidang ilmu-ilmu murni atau disebut juga matematika dan ilmu pengetahuan alam (kelas 5), dan sebanyak 36 penelitian $(1,75 \%)$ pada bidang ilmu pengetahuan sosial (kelas 3).

Sebaran bidang ilmu pada level 2 skema klasifikasi UDC atau setara dengan sub bidang ilmu dapat digambarkan seperti terlihat pada diagram berikut (gambar 2).

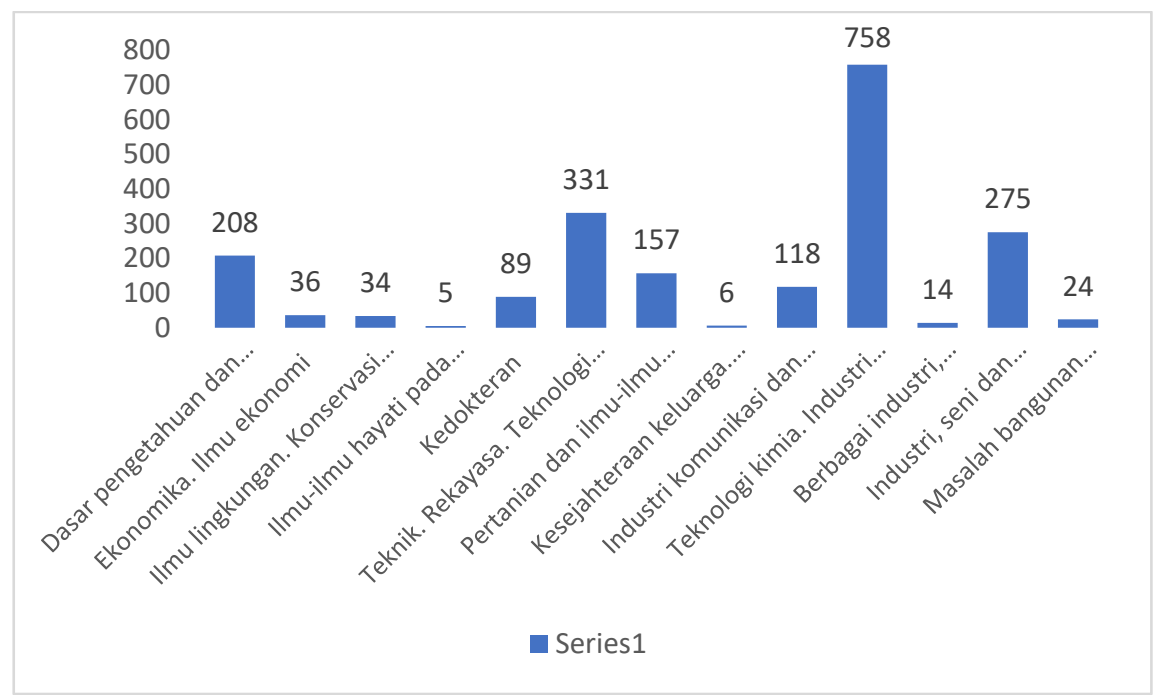

Gambar 2 Sebaran penelitian mahasiswa Fakultas Teknologi Pertanian IPB lulusan tahun 2015-2019 menurut UDC pada level sub bidang ilmu atau level 2.

Dari gambar 2 tersebut terlihat bahwa penelitian terbanyak adalah penelitian terkait "Teknologi kimia. Industri kimia dan yang berhubungan" yaitu sebanyak 758 penelitian atau sebesar 36,89\%. Sedangkan penelitian terkait "ilmu-ilmu hayat pada umumnya" merupakan jumlah penelitian paling sedikit yaitu sebanyak 5 penelitian atau $1,65 \%$.
Secara lebih rinci sebaran bidang ilmu pada penelitian mahasiswa Fakultas Teknologi Pertanian menurut UDC tingkat sub sub bidang ilmu atau level 3 UDC dapat digambarkan dengan diagram seperti terlihat pada gambar 3 berikut. Untuk kemudahan pembacaan diagram maka label bidang ilmu tetap ditulis dengan simbol angka disertai keterangan dari angka-angka simbol tersebut. 


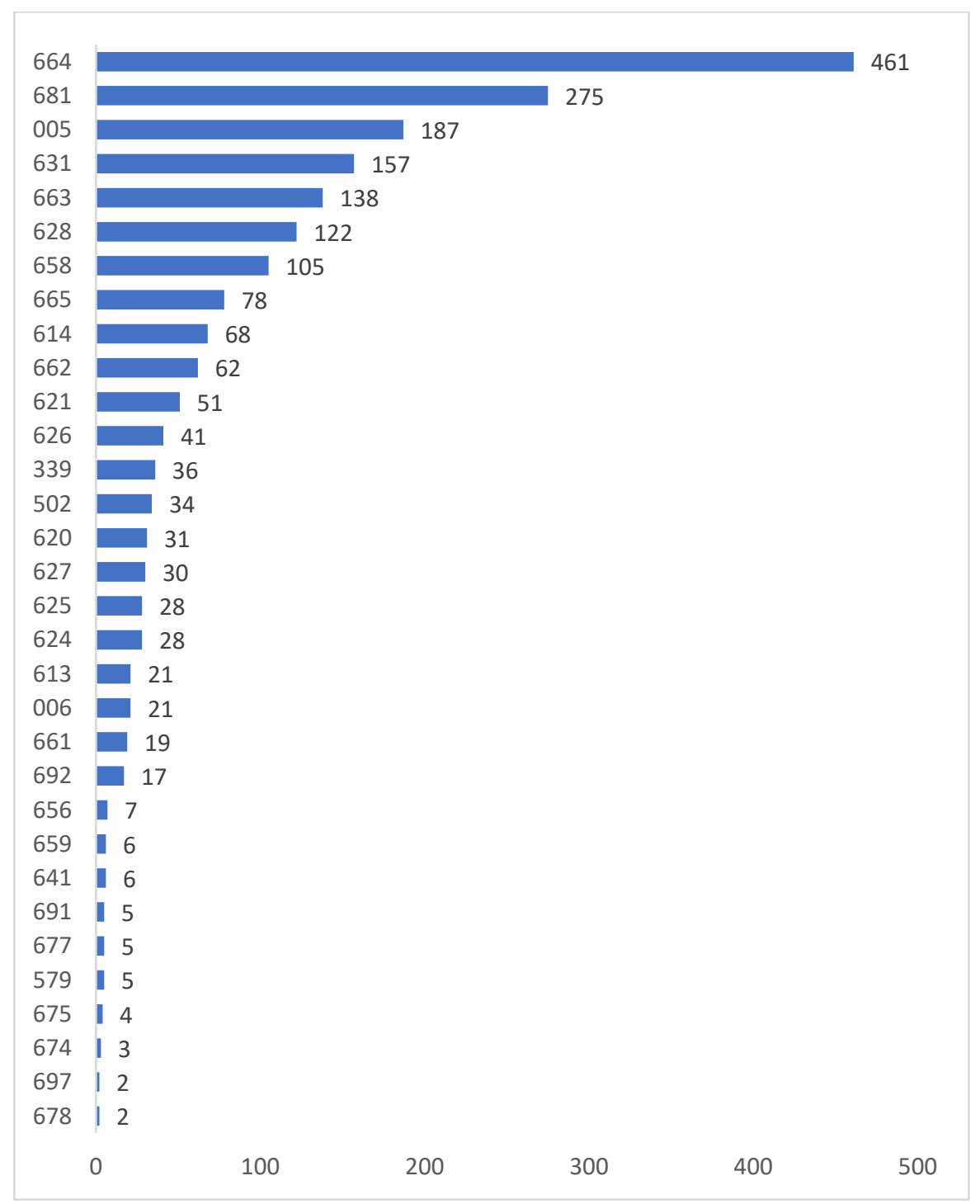

Gambar 3 Sebaran bidang ilmu pada penelitian mahasiswa Fakultas Teknologi Pertanian IPB tahun 2015-2019 menurut klasifikasi UDC pada level 3

Keterangan simbol:

664 Produksi dan pengawetan bahan makanan padat

681 Mekanisme dan instrumen presisi

005 Manajemen

631 Pertanian secara umum

663 Mikrobiologi industri

628 Teknik kesehatan masyarakat. Air. Sanitasi

658 Manajemen, administrasi bisnis. Organisasi komersial

665 Minyak.Lemak. Lilin. Gom. Resin

614 Kesehatan dan kebersihan masyarakat

662 Bahan peledak. Bahan bakar

621 Teknik mekanika pada umumnya

626 Teknik hidraulik

339 Perdagangan. Perniagaan.

502 Lingkungan dan perlindungannya 
620 Pengujian material. Material komersial.Stasiun daya. Ekonomi energi

627 Jalan air alami, bandar, teknik pelabuhan dan pantai.

624 Teknik sipil dan struktur pada umumnya

006 Standarisasi produk, operasi, berat, ukuran dan waktu

613 Kebersihan pada umumnya.

661 Bahan kimia

692 Bagian struktur dan elemen bangunan

656 Jasa angkutan dan pos. Organisasi dan pengendalian lalu lintas.

641 Makanan. Masakan. Hidangan

659 Publisitas. Karya informasi. Hubungan masyarakat

691 Material bangunan. Komponen gedung

677 Industri tekstil

579 Mikrobiologi

675 Industri kulit

674 Kayu dan industri perkayuan

697 Pemanasan. Ventilasi dan penyejukan udara gedung

678 Industri berbasis makromolekul. Industri karet. Plastik.

Dari gambar 3 diagram batang di atas terlihat bahwa ada 32 sub-sub bidang ilmu atau turunan ketiga dari kelompok bidang ilmu utama UDC yang menjadi obyek penelitian mahasiswa Fakultas Teknologi Pertanian IPB tahun 20152019. Lima kelompok penelitian terbanyak adalah penelitian terkait (1) produksi dan pengawetan bahan makanan padat, (2) mekanisme dan instrumen presisi, dan (3) manajemen, (4) pertanian secara umum, dan (5) mikrobiologi industri.

Penelitian terbanyak adalah pada bidang "Produksi dan pengawetan bahan makanan padat" yaitu sebanyak 461 penelitian $(22,43 \%)$. Kelompok ilmu tersebut masih dapat dirinci lebih spesifik lagi yaitu pada tingkat 4 atau level 4 klasifikasi UDC. Terkait penelitian kelompok ilmu "produksi dan pengawetan bahan makanan padat" dirinci menjadi sebanyak 7 topik penelitian dari 8 bidang yang tersedia. Penelitian terbanyak terkait topik ini adalah mengenai teknik pengawetan makanan yaitu sebanyak 68 penelitian. Dari gambar tersebut ternyata diketahui ada satu topik yang tidak pernah diteliti oleh mahasiswa selama 2015-2019 yaitu terkait "mineral dapat dimakan" (lihat gambar 4).

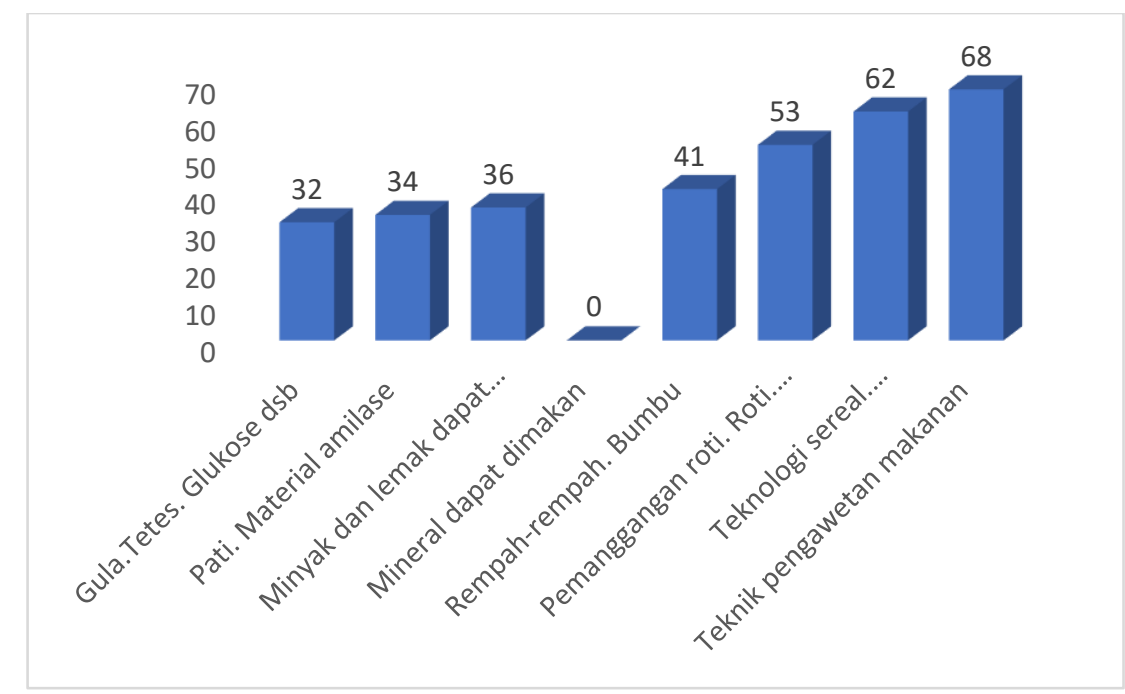

Gambar 4 Rincian topik penelitian terkait "Produksi dan pengawetan bahan makanan padat" pada penelitian mahasiswa Fakultas Teknologi Pertanian IPB tahun 2015-2019 menurut UDC level 4. 
Jumlah penelitian kedua terbanyak adalah penelitian terkait "Mekanisme dan instrumen presisi". Dalam kelompok ilmu ini hanya terdapat satu topik saja yang banyak diteliti yaitu terkait "Teknologi kendali automatik. Teknologi cerdas" dengan jumlah penelitian sebanyak 275 penelitian $(13,38 \%)$. Topik terkait "teknologi kendali otomatik maupun teknologi cerdas" tersebar hampir di semua bidang ilmu, misalnya terkait mesin dan peralatan pertanian, teknologi pengawetan makanan, teknik sipil dan teknik hidrolik, serta industri makanan. Dalam kelompok ini termasuk teknik komputer, teknik robotik, dan pengendali mesin pada industri. Selain pada kelompok "teknologi kendali otomatik" dengan notasi UDC 681.5 maka kelompok lainnya tidak banyak terkait dengan bidang atau topik yang dipelajari di Fakultas Teknologi Pertanian IPB.

Kelompok ketiga terbesar adalah penelitian terkait "manajemen" (kelas 005) yaitu sejumlah 187 penelitian (9,10\%). Namun demikian sebenarnya kelas manajemen tersebut dalam UDC terbagi menjadi dua kelompok yaitu berada di kelas 005 dan yang ditempatkan di kelas 658. Kelas atau kelompok 005 yang terdiri:
005.1 dari teori manajemen,

005.2 agen manajemen, mekanisme, pengukuran,

005.3 aktivitas manajemen,

005.4 proses dalam manajemen,

005.5 operasi manajemen, pengarahan,

005.6 manajemen mutu. Manajemen mutu total (TQM),

005.7 manajemen organisasi,

005.9 bidang manajemen

Jumlah penelitian terbesar pada kelompok ini adalah terkait topik "manajemen mutu. Manajemen mutu total (TQM)" yaitu sebanyak 113 penelitian (5,5\%). Sedangkan sisanya merupakan topik-topik penelitian terkait "Perilaku organisasi. Psikologi manajemen" sebanyak 4 penelitian $(0,19 \%)$, "Proses dalam manajemen" sebanyak 3 penelitian $(0,15 \%)$, "Manajemen pabrik. Manajemen sumber daya fisik" sebanyak 9 penelitian $(0,44 \%)$, dan "Manajemen personel" sebanyak 58 penelitian $(2,82 \%)$. Gambar 5 berikut memperlihatkan sebaran penelitian dengan topik "manajemen" tersebut.

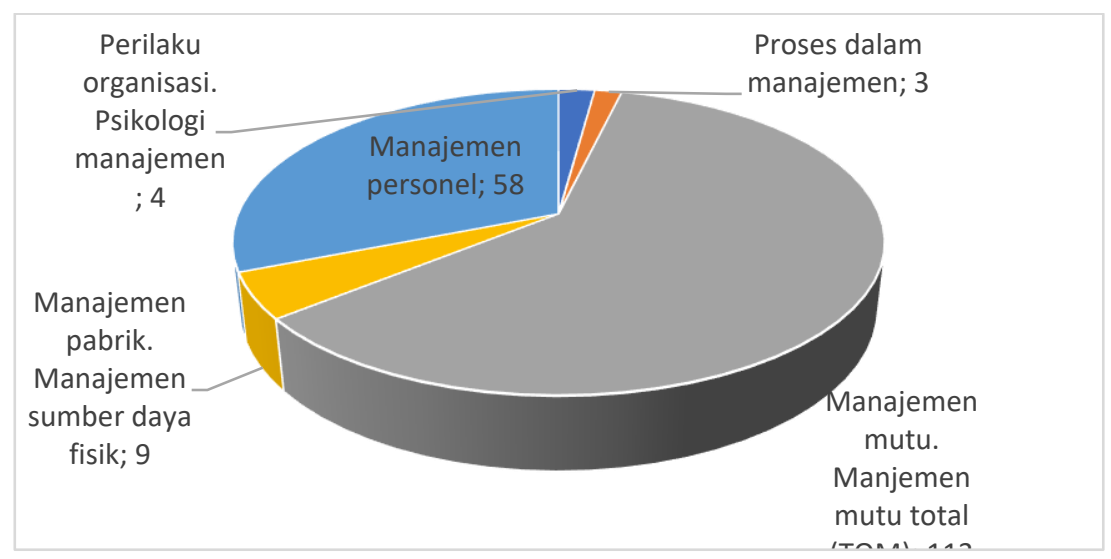

Gambar 5 Sebaran penelitian mahasiswa Fakultas Teknologi Pertanian IPB lulusan 2015-2019 terkait bidang "manajemen" atau dengan kelas 005 pada klasifikasi UDC

Bidang manajemen yang lain oleh UDC ditepatkan di kelas 658 dengan tajuk "Manajemen, administrasi bisnis. Organisasi komersial" yang terdiri dari:

658.1 Bentuk usaha. Keuangan

658.2 Instalasi dan pabrik. Tanah dan bangunan. Gedung, pekerjaan, pabrik. Material

658.3 Hubungan Orang dalam perusahaan. Manajemen kepegawaian
658.5 Teknik dan perencanaan produksi. Desain. Manajemen dan pengendalian produksi

658.6 Organisasi dan praktik komersial. Barang. Jasa

658.7 Pembelian. Pemesanan. Pengadaan. Manajemen stok

658.8 Pemasaran. Penjualan. Menjual. Distribusi

658.9 Aktivitas komersial lainnya 
Pada kelompok 658 ini jumlah penelitiannya cukup banyak yaitu sebanyak 105 penelitian $(5,11 \%)$ dengan jumlah terbesar pada topik terkait "mengenai pemasaran, penjualan, menjual dan distribusi" yaitu sebanyak 71 penelitian $(3,45 \%)$.

Berikutnya adalah penelitian mahasiswa terkait bidang "pertanian secara umum" atau dengan kelas 631 pada klasifikasi UDC. Jumlah penelitian pada kelompok ini juga cukup besar yaitu sebanyak 157 penelitian (7,64\%). Dari 157 penelitian tersebut ternyata didominasi oleh penelitian terkait "mesin pertanian, perkakas dan peralatan pertanian" yaitu sebanyak 127 penelitian (6,18\%). Sisanya merupakan topik-topik terkait "Bangunan pertanian", "Ilmu tanah. Pedologi. Penelitian tanah", dan "operasionalisasi pertanian". Gambaran distribusi topik penelitian tersebut dapat dilihat pada diagram gambar 6 berikut.

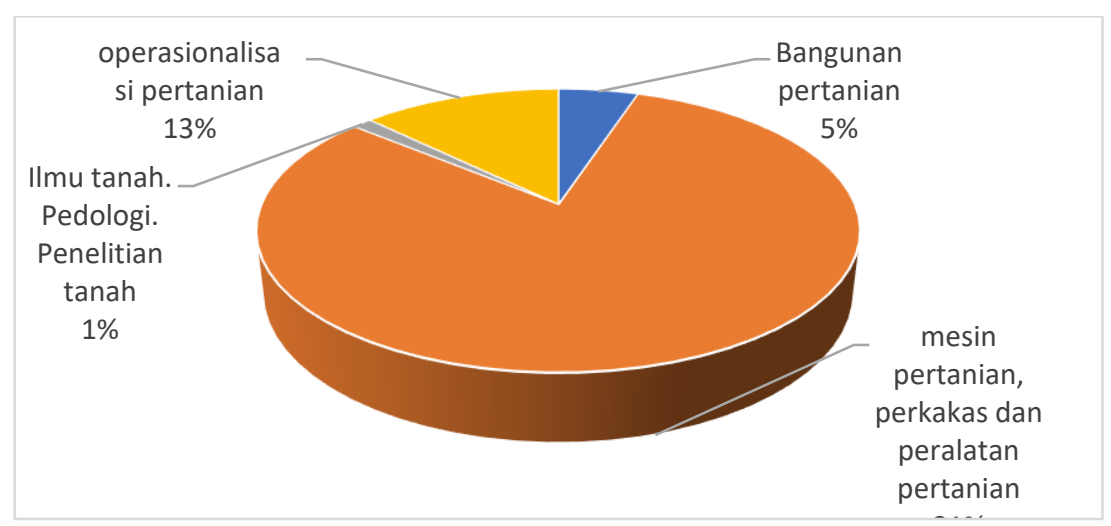

Gambar 6 Sebaran penelitian mahasiswa Fakultas Teknologi Pertanian IPB lulusan 2015-2019 terkait bidang "pertanian secara umum" atau dengan kelas 631 pada klasifikasi UDC

Pada urutan terbesar kelima topik anggur dari tumbuh-tumbuhan" sebanyak 2 penelitian mahasiswa Fakultas Teknologi Pertanian IPB adalah terkait bidang "industri mikrobiologi" (kelas 663) yang merupakan bagian dari "industri kimia" (kelas 66). Pada bidang ini terdapat 138 penelitian atau sebesar 6,72\%. Kelompok ini didominasi oleh penelitian dengan topik "Industri mikrobiologi. Ilmu dan teknik mikologi mikrobiologi terapan" yaitu dengan jumlah penelitian sebanyak 77 penelitian. Selebihnya adalah penelitian terkait "Sari buah apel. Jus pir fermentasi. Anggur buah lainnya, penelitian, "Air untuk minuman ringan dan penggunaan industri lainnya. Air mineral. Air pengobatan" sebanyak 2 penelitian, "Ramuan utama untuk pencampuran minuman. Jus buah dan sayur. Minuman keras. Minuman ringan" sebanyak 22 penelitian, dan yang terakhir terkait "Cokelat. Kakao. Kopi. Teh. Tembakau" yaitu sebanyak 35 penelitian. Gambaran rinci mengenai sebaran topik penelitian terkait industri mikrobiologi tersebut dapat dilihat pada gambar 7 .

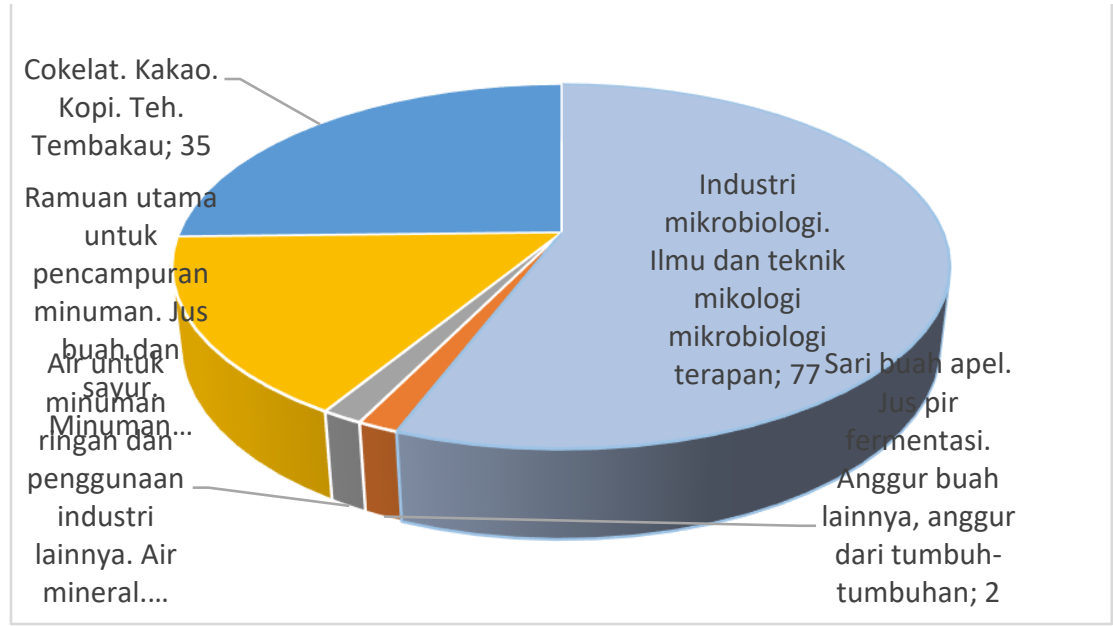

Gambar 7 Sebaran penelitian mahasiswa Fakultas Teknologi Pertanian IPB lulusan 2015-2019 terkait bidang "industri mikrobiologi" atau dengan kelas 663 pada klasifikasi UDC 
Kembali ke Gambar 3 maka terlihat bahwa beberapa komoditas pertanian belum banyak disentuh oleh penelitian mahasiswa seperti "industri kulit" yang hanya 2 penelitian selama kurun waktu 2015-2019. Industri kayu atau perkayuan juga kurang mendapatkan perhatian yaitu hanya ada 3 penelitian. Mungkin terkait kayu dan perkayuan ini bersinggungan dengan Fakultas Kehutanan IPB. Namun demikian perlu dilakukan kajian lebih lanjut agar tidak saling menunggu dan berakibat tidak ada yang melakukan. Begitu juga terhadap industri kulit yang perlu dibahas bersama dengan Fakultas Peternakan karena kulit merupakan hasil sampingan dari produk peternakan.

Selanjutnya beberapa topik terkait teknik sipil memang belum terlalu banyak. Hal ini mengingat Departemen Teknik Sipil dan Lingkungan memang belum lama berdiri dan menghasilkan lulusan. Sebagian penelitian mahasiswa di departemen ini berfokus kepada masalah-masalah lingkungan yaitu "Lingkungan dan perlindungannya" sebanyak 34 penelitian, "Pengawasan dan pengendalian kebersihan" sebanyak 33 penelitian dan "Pencemaran dan pengendaliannya" sebanyak 32 penelitian. Beberapa penelitian memang terkait teknik sipil yang berfokus pada teknik hidrolika yaitu sebanyak 41 penelitian.

\section{Peta bibliometrik kata kunci berdasarkan VosViewer}

Basis data skripsi lulusan Fakultas Teknologi Pertanian IPB yang ada di Perpustakaan IPB dilengkapi dengan kata kunci. Sayangnya, kata kunci tersebut dibuat sendiri oleh penulisnya sehingga bentukan kata kunci tersebut lebih mengarah kepada "bahasa alami" atau di dalam ilmu perpustakaan dikenal dengan istilah "natural language". Dengan demikian maka banyak kata kunci yang dibuat oleh penulis skripsi tersebut tidak terstandar. Satu-satunya yang terstandar adalah kata kunci tersebut dibuat dalam bahasa Inggris. Namun demikian, kajian ini menemukan banyak kesalahan terjemahan kata kunci tersebut, misalnya makanan cemilan yang dalam bahasa Inggris disebut "snack" oleh penulis skripsi disajikan dengan tulisan "snake" yang berarti ular. Dengan demikian, kata kunci tersebut dapat menyesatkan para pencari informasi. Selain itu, karena ketidak-fahaman penulis skripsi maka banyak kata-kata memiliki arti umum dijadikan sebagai kata kunci, misalnya "air atau water", "suhu atau temperature" dan masih banyak contoh lainnya. Untuk mendapatkan peta kata kunci yang punya arti maka kata-kata kunci yang dirasa kurang tepat dalam kajian ini terpaksa dibuang. Selain itu kajian ini menambahkan kata kunci yang berasal dari Skema Klasifikasi UDC di mana kata kunci seperti ini dalam ilmu perpustakaan disebut sebagai bahasa terkontrol atau "controlled language". Sesudah menghilangkan beberapa kata kunci yang dirasa kurang pas, dan menambahkan kata kunci yang berasal dari skema klasifikasi UDC maka diperoleh hasil sebagai berikut:

1. Jumlah kata kunci yang dibuat oleh penulis skripsi sesudah dikoreksi kemudian ditambah kata kunci yang berasal daru skema klasifikasi UDC berjumlah 7.968 kata kunci. Rata-rata kata kunci setiap skripsi adalah 7 kata kunci. Jumlah kata kunci terbanyak pada skripsi Fateta IPB berjumlah 10 kata kunci untuk setiap skripsi yaitu sebanyak 179 skripsi, sedangkan yang paling sedikit adalah 3 kata kunci yaitu pada 2 judul skripsi.

2. Kata kunci yang paling sering muncul adalah "teknik pengawetan makanan" dengan jumlah kemunculan sebanyak 278 kali. Sedangkan kata kunci "teknologi cerdas" muncul sebanyak 143 kali dan "manajemen mutu muncul sebanyak 110 kali.

3. Untuk kemunculan kata kunci paling sebanyak paling sedikit 4 kali maka jumlah kata kunci tersebut adalah berjumlah 569 kata kunci. Keterhubungan (link) kata kunci yang paling kuat adalah "teknik pengawetan makanan" dengan total kekuatan keterhubungan sebesar 605 hubungan. Sedangkan kekuatan keterhubungan kata kunci "teknologi cerdas" sebesar 220 hubungan dan untuk kata kunci "manajemen mutu" sebesar 117 hubungan.

\section{Visualisasi network peta kata kunci atau co-word}

Hasil visualisasi network peta co-word perkembangan penelitian mahasiswa di Fakultas Teknologi Pertanian IPB terlihat seperti pada gambar 8 berikut. 


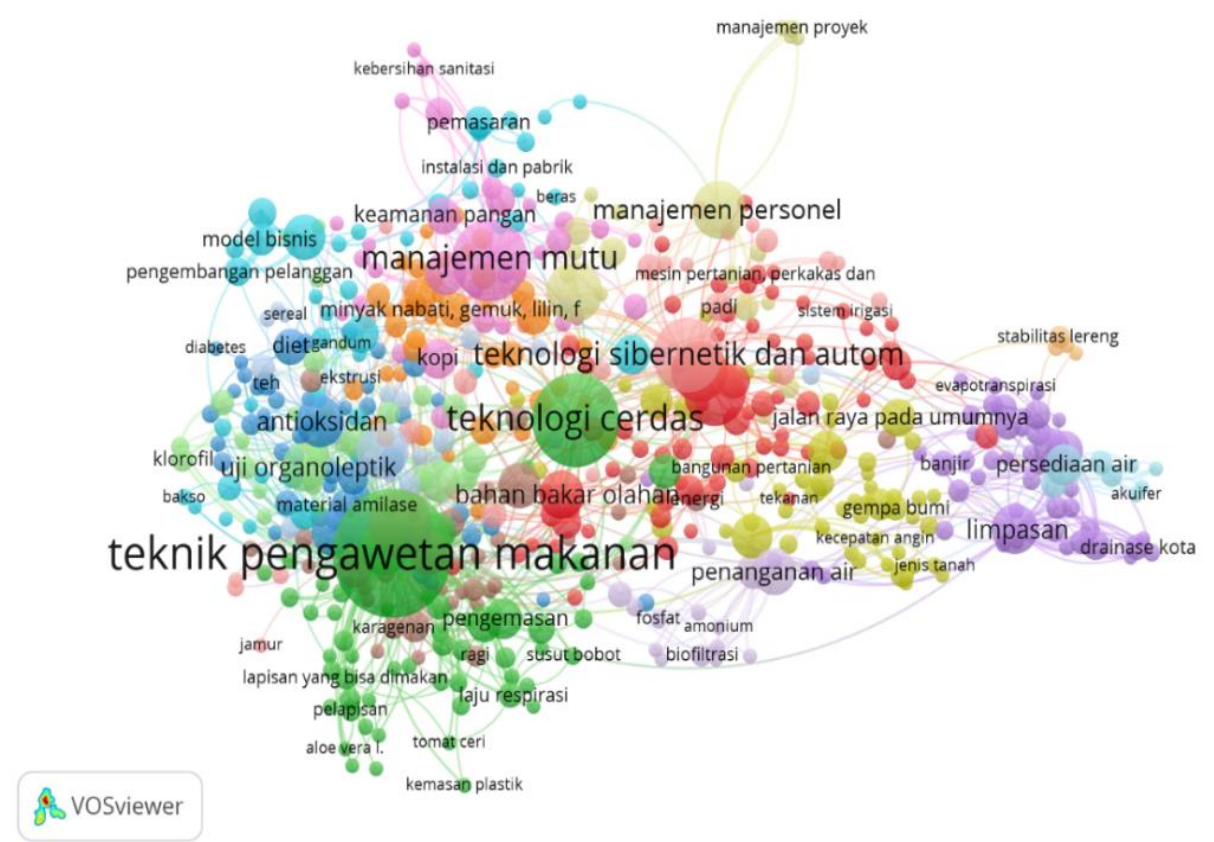

Gambar 8 Peta co-word dengan batasan kemunculan kata kunci sekurang-kurangnya 4 kali pada skripsi lulusan Fakultas Teknologi Pertanian IPB tahun 2015-2019

Gambar 8 tersebut merupakan peta coword dengan batasan kemunculan kata kunci sekurang-kurangnya 4 kali. Penelitian tersebut terbagi menjadi 16 kluster dengan kluster terbesar yaitu kluster 1 terdiri dari 69 kata kunci dan kluster yang paling kecil yaitu kluster 16 terdiri dari 4 kata kunci. Gambar bulatan (bullet) pada peta tersebut memperlihatkan jumlah kata kunci yang muncul pada dokumen yang dianalisis. Semakin besar ukuran "bulatan" tersebut, semakin banyak jumlah kata kunci yang ditemukan dalam dokumen yang dianalisis. Demikian juga sebaliknya, semakin kecil ukuran "bulatan" tersebut, maka semakin sedikit jumlah kata kunci yang ditemukan pada dokumen yang dianalisis. Pada gambar 8 di atas terlihat ukuran "bulatan" yang menggambarkan "teknik pengawetan makanan" paling besar. Hal ini menandakan bahwa kata kunci "teknik pengawetan makanan" merupakan jumlah yang terbanyak dibandingkan dengan kata kunci yang lain seperti "teknologi cerdas" dan "manajemen mutu".

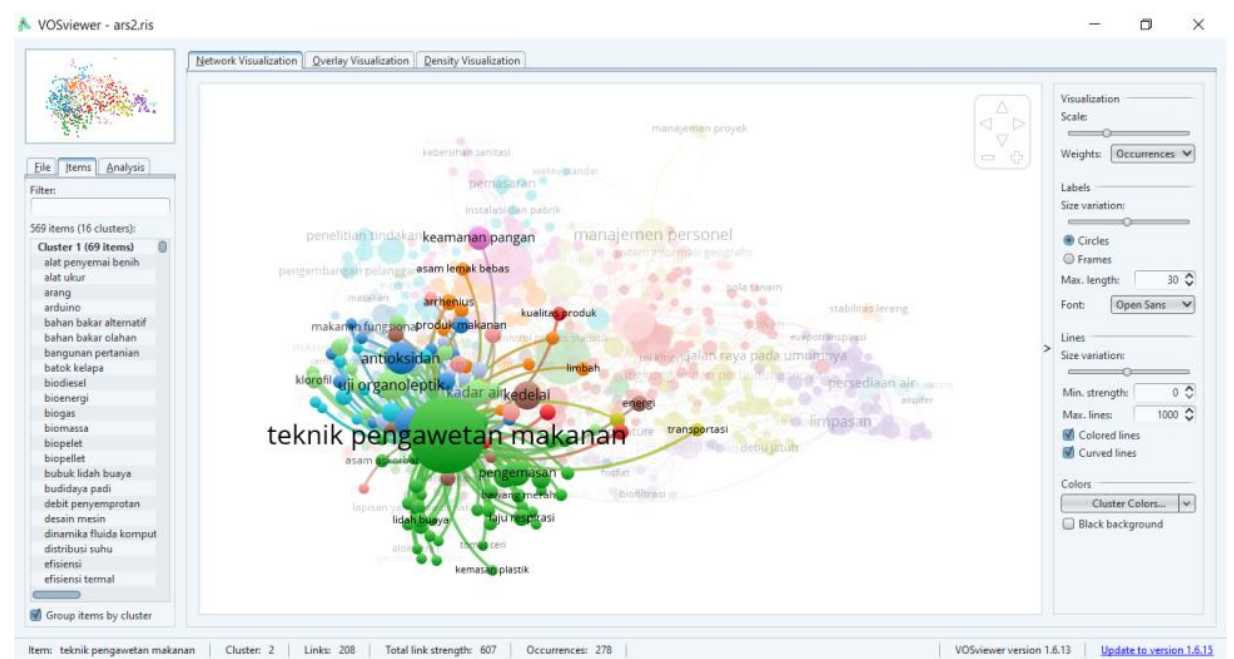

Gambar 9 Peta kluster pada kata kunci “teknik pengawetan makanan” yang terdapat dalam skripsi lulusan Fakultas Teknologi Pertanian IPB tahun 2015-2019 
Kata kunci "teknik pengawetan makanan" merupakan kata kunci yang muncul paling banyak dengan kekuatan keterhubungan (link) paling kuat. Gambar 9 menampilkan peta untuk kata kunci "teknik pengawetan makanan". Sedangkan peta untuk kata kunci "teknologi cerdas" digambarkan pada gambar 10 dan peta untuk kata kunci "manajemen mutu" digambarkan pada gambar 11.

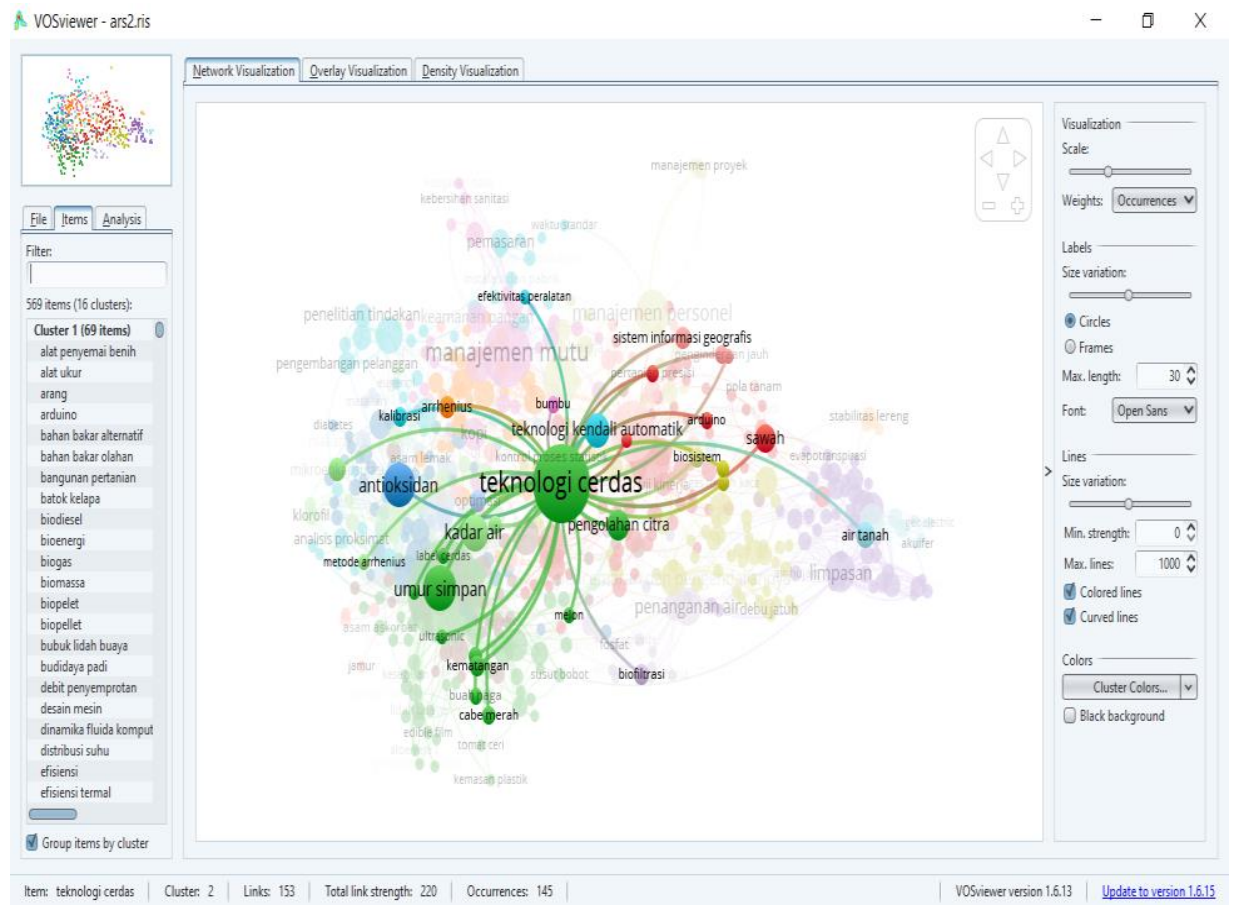

Gambar 10 Peta kluster pada kata kunci "teknologi cerdas" yang terdapat dalam skripsi lulusan Fakultas Teknologi Pertanian IPB tahun 2015-2019

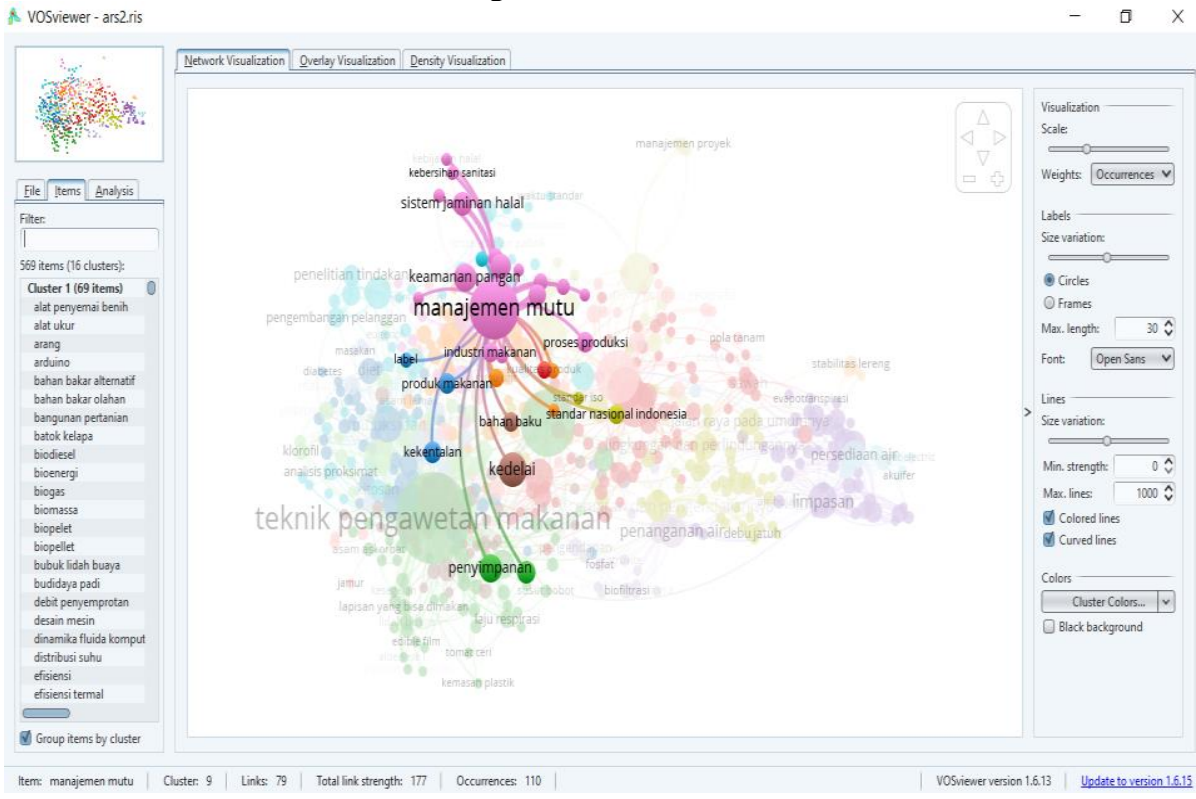

Gambar 11 Peta kluster pada kata kunci "manajemen mutu" yang terdapat dalam skripsi lulusan Fakultas Teknologi Pertanian IPB tahun 2015-2019

\section{Visualisasi Density Peta Co-word}

Cara lain untuk melihat peta co-word atau peta kata kunci pada perkembangan penelitian dalam bidang ilmu tertentu adalah dengan visualisasi densiti atau "density visualization". 


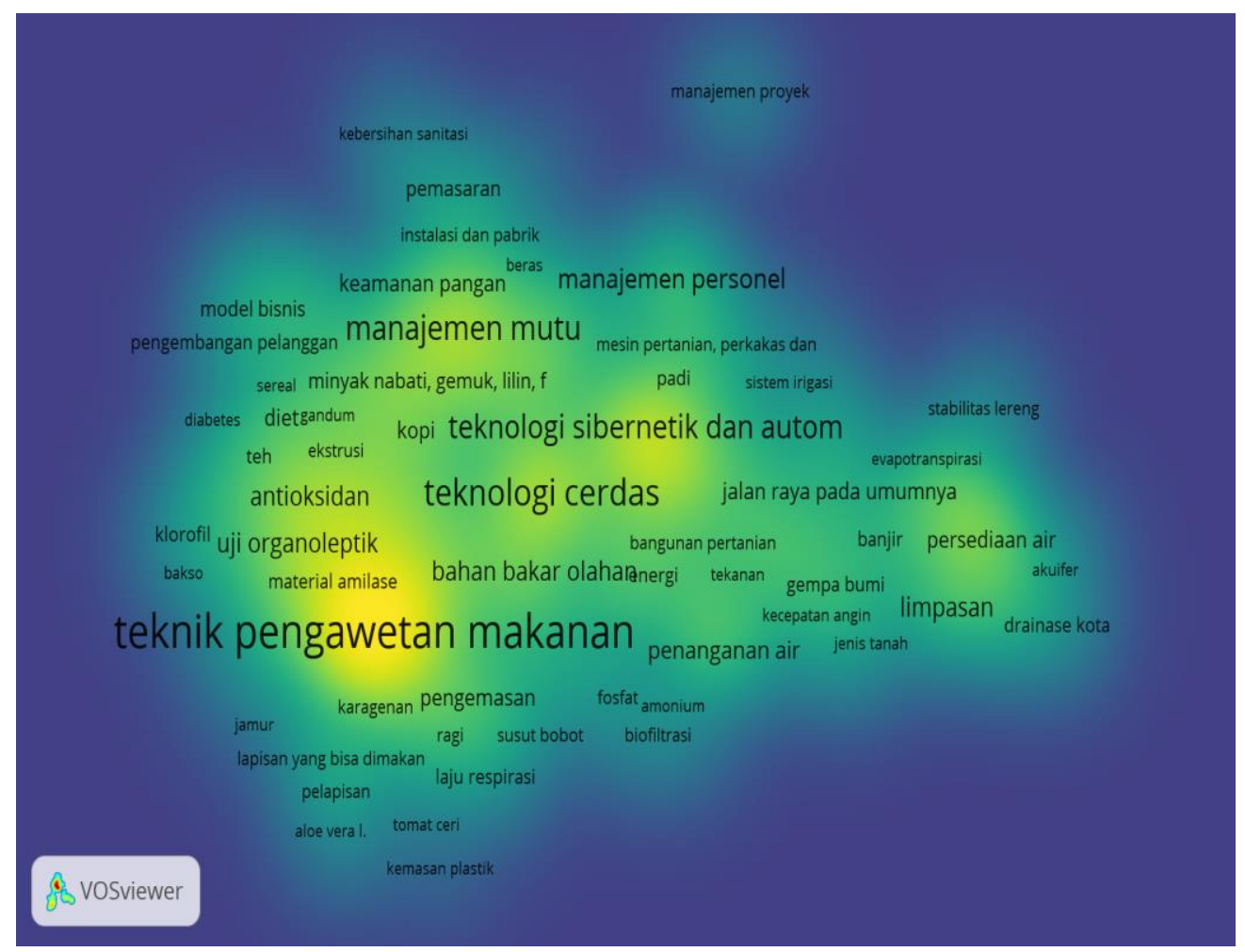

Gambar 12 Visualisasi densiti (density visualization) peta co-word pada penelitian mahasiswa Fakultas Teknologi Pertanian IPB tahun 2015-2019

Pada peta visualisasi ini kepadatan kata kunci atau co-word diperlihatkan menggunakan warna. Semakin padat warna yang digambarkan pada peta, maka semakin padat volume kata kunci tersebut. Begitu juga sebaliknya, semakin tipis warna yang ditampilkan, maka semakin kecil kepadatan kata kunci tersebut. Gambar 12 memperlihatkan gambaran tingkat kepadatan kata kunci pada penelitian mahasiswa Fakultas Teknologi Pertanian IPB tahun 2015-2019.

Melalui peta visualisasi densiti pada gambar 12 tersebut kita dapat menafsirkan bahwa penelitian terkait "teknik pengawetan makanan" merupakan topik penelitian terbanyak yang divisualisasikan dengan warna kuning yang paling pekat dibandigkan dengan topik-topik yang lain.

\section{Produktivitas Dosen Pembimbing}

Dari hasil kajian diperoleh hasil bahwa dosen pembimbing paling produktif sebagai pembimbing utama selama lima tahun terakhir atau periode 2015-2019 adalah Arief Sabdo Yuwono dengan jumlah bimbingan sebanyak 31 mahasiswa. Sedangkan kedua paling produktif adalah Yudi Chadirin dan Roh Santoso Budi Waspodo dengan jumlah bimbingan masingmasing sebanyak 27 mahasiswa, dan ketiga paling produktif adalah Nora Herdiana Panjaitan, Prastowo, Satyanti Krido Saptomo, dan Budi Indra Setiawan yaitu masing-masing sebanyak 25 mahasiswa. Berikutnya dengan 24 mahasiswa bimbingan adalah Elisa Anggraeni dan Taufik Djatna; dengan 23 mahasiswa bimbingan adalah Emmy Darmawati dan Yohanes Aris Purwanto; dengan 22 mahasiswa bimbingan adalah Chusnul Arif, Liyantono, Sapta Raharja, Asep Sapei; dengan 21 mahaiswa bimbingan adalah Usman Ahmad, Desrial, Hartrisari Hardjomidjojo, Gatot Pramuhadi, Kudang Boro Seminar, Suprihatin, M Faiz Syuaib, Endang Wariski; dan dengan 20 mahasiswa bimbingan adalah Erizal, Aji Hermawan, Sam Herodian, dan Marimin. Selebihnya sebanyak 125 dosen membimbing antara 1 orang mahasiswa sampai 19 orang mahasiswa. Tabel 2 berikut adalah produktivitas dosen pembimbing yang membimbing 20 mahasiswa atau lebih. 
Tabel 2 Produktivitas dosen pembimbing utama Fakultas Teknologi Pertanian IPB tahun 2015-2019

\begin{tabular}{rllllllll}
\hline \multirow{2}{*}{ No. } & \multicolumn{7}{c}{ Jumlah Mahasiswa Bimbingan } \\
\cline { 2 - 8 } & $\mathbf{3 1}$ & $\mathbf{2 7}$ & $\mathbf{2 5}$ & $\mathbf{2 4}$ & $\mathbf{2 3}$ & $\mathbf{2 2}$ & $\mathbf{2 1}$ & $\mathbf{2 0}$ \\
\hline 1 & ASY & YCH & NHP & EAN & EDA & CAR & UAH & ERI \\
2 & & RSBW & PRAS & TDJ & YAP & LIY & DES & AHE \\
3 & & & SKS & & & SRA & HHA & WHE \\
4 & & & BIS & & & ASA & GPR & SHE \\
5 & & & & & KBS & MAR \\
6 & & & & & & SUP & \\
7 & & & & & & MFS & \\
8 & & & & & & EWR & \\
\hline
\end{tabular}

Pembimbing anggota paling produktif adalah Muhammad Arif Darmawan dan Didah Nur Faridah dengan jumlah bimbingan masingmasing sebanyak 19 orang mahasiswa, diikuti oleh kedua paling produktif yaitu Muhammad Fauzan dengan bimbingan sebanyak 14 orang mahasiswa. Sedangkan ketiga paling produktif adalah Andes Ismayana dan Muhamad Yani dengan jumlah bimbingan sebanyak 13 orang mahasiswa. Selanjutnya dosen dengan jumlah mahasiswa bimbingan sebanyak 11 orang mahasiswa adalah Winiati Pudji Rahayu, Tri Sudibyo, Slamet Widodo, Muhamad Yulianto; kemudian dosen dengan jumlah bimbingan sebanyak 10 orang mahasiswa adalah Nuri Andarwulan, Gustan Pari, Azis Boing Sitanggang, Sutoyo, Yanuar Chandra Wirasembada; dosen dengan bimbingan sebanyak 9 orang mahasiswa adalah Dede Robiatul Adawiyah, Made Astawan, Siti Nurjanah, Titi Candra Sunarti; Dosen dengan jumlah bimbingan sebanyak 8 orang mahasiswa adalah Dase Hunaefi, Satyanto Krido Saptomo, Suprihatin, Prayoga Suryadarma; dan dosen dengan jumlah bimbingan sebanyak 7 orang mahasiswa adalah Erliza Hambali dan Yudi Setiawan. Tabel 3 berikut adalah gambaran produktivitas dosen pembimbing kedua pada Fakultas Teknologi Pertanian IPB selama 2015-2019.

Tabel 3 Produktivitas dosen pembimbing anggota Fakultas Teknologi Pertanian IPB tahun 2015-2019

\begin{tabular}{|c|c|c|c|c|c|c|c|c|}
\hline \multirow{2}{*}{ No. } & \multicolumn{8}{|c|}{ Jumlah Bimbingan } \\
\hline & 19 & 14 & 13 & 11 & 10 & 9 & 8 & 7 \\
\hline 1 & MAD & MFA & AIS & WPR & NAD & DRA & $\mathrm{DHU}$ & EHA \\
\hline 2 & DNF & & MYA & TSU & GPA & MAS & SKS & YSE \\
\hline 3 & & & & SWI & ABS & SNU & SUP & \\
\hline 4 & & & & MYU & SUT & TCS & PSU & \\
\hline 5 & & & & & YCM & & & \\
\hline
\end{tabular}

\section{KESIMPULAN}

Dari hasil kajian dapat ditarik beberapa kesimpulan sebagai berikut:

1. Jumlah penelitian skripsi mahasiswa Fakultas Teknologi Pertanian IPB selama lima tahun terakhir (2015-2019) berjumlah 2.055 judul penelitian. Jumlah tersebut terdiri atas skripsi mahasiswa Departemen TMB sebanyak 519 judul penelitian (25,26\%), Departemen ITP sebanyak 607 judul penelitian (29,54\%), Departemen TIN sebanyak 572 judul penelitian $(27,83 \%)$, dan Departemen SIL sebanyak 357 judul penelitian $(17,37$.

2. Berdasarkan tahun kelulusan, jumlah skripsi terbanyak berada pada tahun 2017 yaitu sebanyak 459 judul, kemudian diikuti tahun 2016 sebanyak 413 judul, 2018 sebanyak 402 judul, tahun 2019 sebanyak 393 judul dan paling sedikit adalah pada tahun 2015 yaitu berjumlah 388 judul.

3. Penelitian mahasiswa Fakultas Teknologi Pertanian IPB selama 2015-2019 meliputi empat kelompok utama UDC yaitu bidang "ilmu terapan, kedokteran, dan teknologi" sebanyak 1.772 penelitian, diikuti oleh "sain dan pengetahuan" sebanyak 208 penelitian, kelompok "matematika, IPA" sebanyak 39 penelitian dan ilmu sosial sebanyak 39 penelitian. 
4. Topik kajian paling banyak diteliti adalah "Produksi dan pengawetan bahan makanan padat" dengan jumlah penelitian sebanyak 461 judul penelitian, sedangkan yang paling sedikit adalah topik terkait "ventilasi dan penyejukan udara" dan "industri karet" dengan jumlah penelitian masing-masing sebanak 2 judul penelitian.

5. Kata kunci yang paling sering muncul adalah "teknik pengawetan makanan" dengan jumlah kemunculan sebanyak 278 kali. Sedangkan kata kunci "teknologi cerdas" muncul sebanyak 143 kali dan "manajemen mutu muncul sebanyak 110 kali.

6. Untuk kemunculan kata kunci paling sebanyak paling sedikit 4 kali maka jumlah kata kunci tersebut adalah berjumlah 569 kata kunci. Keterhubungan (link) kata kunci yang paling kuat adalah "teknik pengawetan makanan" dengan total kekuatan keterhubungan sebesar 605 hubungan. Sedangkan kekuatan keterhubungan kata kunci "teknologi cerdas" sebesar 220 hubungan dan untuk kata kunci "manajemen mutu" sebesar 117 hubungan.

7. Menurut kata kunci pada analisis co-word menggunakan VosViewer penelitian mahasiswa Fakultas Teknologi Pertanian IPB tahun 2015-2019 terbagi menjadi 16 kluster dengan kluster terbesar yaitu kluster 1 terdiri dari 69 kata kunci dan kluster yang paling kecil yaitu kluster 16 terdiri dari 4 kata kunci.

8. Dosen pembimbing utama paling produktif adalah Arif Sabdo Yuwono dengan jumlah bimbingan sebanyak 31 orang mahasiswa. Sedangkan sebagai dosen pembimbing anggota paling produktif adalah Muhammad Arif Darmawan dan Didah Nur Faridah dengan jumlah bimbingan masing-masing sebanyak 19 orang mahasiswa.

\section{Daftar Pustaka}

Agrotek Pertanian. (2017, 11 05). Faktorfaktor produksi pertanian. Diambil kembali dari Agrotek Pertanian: https://jaenuriblog.wordpress.com/ 2017/11/05/faktor-faktorproduksi-pertanian/
Concortium, U. (2019). UDC Master Reference File 12. Dipetik May 18, 2019, dari Universal Decimal Classification Concortium: http://www.udcc.org/

Gischa, S. (2019, 12 12). Indonesia sebagai

Negara Agraris, Apa Artinya? Diambil kembali dari Kompas.com: https://www.kompas.com/skola/re $\mathrm{ad} / 2019 / 12 / 12 / 172322669 /$ indone sia-sebagai-negara-agraris-apaartinya?page $=$ all

Helmi, M. (2014, November 28). Machdarhelmi. Dipetik January 5, 2018, dari Pengertian skripsi, tesis, disertasi, karangan ilmiah populer dan jurnal: https://machdarhelmi. wordpress.com/2014/11/28/penge rtian-skripsi-tesis-disertasi-karanganilmiah-populer-jurnal/

Hidayat, A. (2012, October 19). Penjelasan Analisis Deskriptif dan Tutorialnya Dengan Excel. Dipetik May 18, 2019, dari Statistikian: https://www.statistikian.com/2012 /10/analisis-deskriptif-denganexcel.html

Institut Pertanian Bogor. (2017). Panduan program pendidikan sarjana. Bogor: IPB.

Kementerian Sekretariat Negara RI. (2015). Peraturan Presiden RI Nomor 2 Tabun 2018 tentang Kebijakan Industri Nasional Tahun 2015-2019. Jakarta: Sekretariat Negara.

Maulana, R. F. (2019, 01 14). Berkurangnya laban pertanian di Indonesia. Diambil kembali dari Kompasiana: https://www. kompasiana.com/firkan/5c3c89f34 3322f320330e6e5/berkurangnyalahan-pertanian-diindonesia?page $=$ all

Muljono, P., Sujana, J., \& Prabowo, B. (2009). Metodologi Penelitian dan Laporan Kearsipan. Jakarta: Penerbit Universitas Terbuka.

Nugroho, A. B. (2015, 09 11). Memahami sifat produk pertanian secara bijak. 
Diambil kembali dari Konsultan Karya Tulis Ilmiah:

https://konsultankti.wordpress.com /2015/09/11/memahami-sifatproduk-pertanian-dan-sifatproduksi-pertanian-secara-bijak/

Purwoko. (2020). Mengenal fitur Vosviewer dan arti visualisasinya \#1. Dipetik September 10, 2020, dari grenengane pustakawan: http://www.purwo.co/2019/05/m engenal-fitur-vosviewer-danarti.html

Rahayu, S., \& Saleh, A. (2017). Studi bibliometrik dan sebaran topik penelitian pada Jurnal Hayati terbitan 2012-2016. Pustakaloka, 9(2), 201-218. doi:

https://doi.org/10.21154/pustakalo ka.v9i2.1092

Ratnaningsih, \& Himawan, D. (2016). Peningkatan Layanan Data dan Informasi dalam rangka Memenubi Kebutuhan Informasi di Perpustakaan Perguruan Tinggi (Suatu Kajian Deskriptif Analisis terhadap 5 Bunga Komersial Utama dan 7 Bunga Potensial Komersial). Dipetik May 18, 2019, dari IPB Scientific Repository: https:/ / repository.ipb.ac.id/handle/ 123456789/93672

Ratnaningsih, R., \& Atnah, A. (2019). Pemetaan Bidang Ilmu Pada Skripsi Fakultas Ekologi Manusia Lulusan Tabun 2014-2018 Berdasarkan Standar Universal Decimal Classification . Bogor: Institut Pertanian Bogor.

Ratnantingsih, Himawan, D., \& Saleh, A. (2019). Peta penelitian terhadap 12 buah lokal Indonesia pada skripsi, tesis dan disertasi lulusan IPB . Visi Pustaka vol. 19 nomor 3, Desember 2017, hal. 191-201, 19(3), 191-201.

Saleh, A. (2018). Pemetaan bidang ilmu pada skripsi Fakultas Peternakan
IPB lulusan tahun 2012-2016 sesuai Universal Decimal Classification. Seminar Nasional Jabatan Fungsional: Strategi peningkatan profesionalisme dan kompetensi aparatur sipil negara (ASN) pada jabatan fungsional (hal. 174-184). Bogor: Fakultas Matematika dan Ilmu Pengetahuan Alam, Institut Pertanian Bogor.

Saleh, A. R., \& Himawan, D. (2019). Pemetaan Informasi Sebaran Bidang Ilmu pada Penelitian Skripsi Fakultas Perikanan dan Ilmu Kelautan IPB Lulusan Tahun 20142018 Berdasarkan Standar Universal Decimal Classification. Visi Pustaka, 21(3), 227-240.

Sugiyono. (2014). Metode penelitian manajemen: Pendekatan kuantitatif, kualitatif, kombinasi, penelitian tindakan, penelitian evaluasi. Bandung: Alfabeta.

Sulistyo-Basuki. (1991). Pengantar ilmu perpustakaan. Jakarta: Gramedia Pustaka Utama.

Susanto, D. (2018, 11 16). Masibkan Indonesia negara agraris? Diambil kembali dari Detik News: https://news.detik.com/kolom/d4304718/masihkah-indonesianegara-agraris

Tanjung, B., \& Ardial. (2007). Pedoman penulisan karya ilmiah (proposal, skripsi, dan tesis) dan mempersiapkan diri menjadi penulis artikel ilmiah. Jakarta: Kencana.

Tupan. (2016). Pemetaan bibliometrik dengan VosViewer terhadap perkembangan hasil penelitian bidang pertanian di Indonesia. Visi Pustaka, 18(3), 217-230.

Wikipedia. (2017, November 27). Ilmu. Dipetik January 11, 2018, dari https://id.wikipedia.org/wiki/Ilmu 